\title{
COOPERATION SCIENCE-BUSINESS AS AN OPPORTUNITY FOR DEVELOPMENT AND COMPETITIVENESS OF THE ENTERPRISE AND ECONOMY
}

\author{
Anna Majzel ${ }^{1}$, Magdalena Byczkowska ${ }^{2}$, Janusz Soboń ${ }^{3}$ \\ Wydział Ekonomiczny, Akademia im. Jakuba z Paradyża w Gorzowie Wielkopolskim, \\ ul. Teatralna 25, 66-400 Gorzów Wielkopolski, Poland \\ E-mails: ${ }^{1}$ majzelania@gmail.com (corresponding author); ${ }^{2}$ magdabyczkowska@wp.pl; ${ }^{3}$ sj@list.home.pl
}

Received 29 February 2020; accepted 06 May 2020

\begin{abstract}
The aim of the article is to present the essence of cooperation between science and business and to identify the gap that exists in this area in Poland. To this end, as a research method, a comparative analysis of the literature on the subject was used. As a starting point, it was assumed that cooperation between science and business is the domain of developed countries' economies, and Poland, like other post-socialist countries, is still learning how to create and maintain such cooperation. The international comparison presented in the text (Germany as a model of conducting joint scientific-business projects; Poland and the Czech Republic as countries building such links) allows to show the existing gap in this area and indicate the postulates of creating activity in this area both for entrepreneurs and business-related institutions, which should be used by participants of modern economic markets.
\end{abstract}

Keywords: cooperation, development, competitiveness, science, business.

JEL Classification: O32.

\section{Introduction}

Effective management of a modern enterprise requires managers not only excellent knowledge of management methods and techniques but also (or perhaps most importantly) the ability to use innovative solutions, not yet known.

Basing the strategy of competition or development only on cost assumptions is insufficient in the current economic reality.

The new paradigm of competitiveness of enterprises (Białasiewicz, 2009) draws particular attention to the importance of horizontal relations and links and to the creation of knowledge-based business value (Głodek, 2019; Patalas-Maliszewska, 2019). Such an approach is a requirement of the modern environment, the shape of which is determined by the progressing globalization processes (Stawicka \& Noga, 2008). The importance of these processes is reflected in the strategic documents of Poland and the European Union. They stress the need to support innovative enterprises connected with modern technologies; they also pay attention to lifelong learning, which is to be a response to rapidly changing market structures and frequent obsolescence of knowledge. Among others, such activities (although there are many more of them) are seen as an opportunity to shape the competitiveness of the economy.
One such solution, which encourages the creation of innovative concepts or solutions, is the creation of a business model based on links with the sphere of science. This is a relatively young subject, both for the Polish economy and for Polish scientists. Functioning for years in accordance with the principles of a centrally controlled economy did not force managers to undertake any activities that would support the competitiveness of an enterprise. Only the accession to the European Union showed openly that our domestic enterprises are managed inefficiently; the emerging competition verified the way Polish entities function on the market. Foreign companies appearing in Poland were well prepared for competitive struggle - years of doing business on the principles of the free-market economy brought obvious results. It was only then that Polish entrepreneurs began to learn what real business, risk, competition are - and they continue to learn the art of management. At the same time, opportunities for horizontal cooperation (clusters, strategic alliances, and others) are slowly appearing in the consciousness of entrepreneurs; more and more often, they also decide to cooperate with the world of science (Gabryś, 2008).

The relationship between science and business is seen as a natural phenomenon in the economies of developed countries. There is no tradition of such cooperation in Poland, but for several years we have been observing more and more such initiatives. The 
article presents basic issues related to the essence of such cooperation - its benefits and barriers, theoretical considerations, but also the results of research related to this subject.

\section{Science-business cooperation in selected countries}

When analyzing the history of entrepreneurship and highly developed countries, special attention should be paid to the networks of connections created by market participants. These links often concern entities that can be considered competitive with each other (e.g., within a cluster (Szopik-Depczyńska et al., 2018; Moczała et al., 2016)). However, we also find a lot of cooperation within the framework of public-private partnerships, an example of which is science-business cooperation.

In order to better describe the above topic, this chapter presents the most important assumptions on strengthening such cooperation in three countries: Poland, the Czech Republic (as a country with similar economic history) and Germany (as a developed country with a greater tradition of this type of collaboration).

Just as in Poland there is no tradition of science-business cooperation in the Czech Republic, this area is seen as a major shortcoming in the development of the Czech economy. Kaderabkova (2007) argues that Czech regional policy is also a weakness, although attention should be paid to the assumptions of regional innovation strategies that have been emerging for several years. These strategies take into account the specificity of regions, but also involve foreign partners.

One example of successful cooperation between science and business in the Czech Republic is the Technology Transfer Office (TTO) of Masaryk University in Brno. The entity's tasks are primarily related to commercialization, in particular:

- preparation of the concept of commercialization (it depends, among other things, on the specificity, size of the market),

- developing an intellectual property protection strategy,

- determining the terms and conditions of licensing,

- is a bridge between the bidder and the purchaser of the research results (it negotiates in this respect),

- allowing access to a wide range of specialists,

- presenting to scientists possible paths of commercialization and sources of their financing,
- initiating links between the university and the region's enterprises (Kaderabkowa, 2007).

When comparing Polish and Czech experiences in the field of science-business cooperation, it is necessary to pay attention to the elements that should be adapted by Polish model solutions:

- the activities of the Technology Transfer Office are focused on the scientist - the entity offers comprehensive advice on intellectual property protection,

- the costs of patent protection are reimbursed to Technology Transfer Office; moreover, the TTO also receives additional funds and their amount is adequate to the number of patent applications. Thus, patent applications are not a financial burden for the University. It is also very important for Polish science, which has been underfunded for many years. Such a solution would undoubtedly affect the number and quality of patent applications, possibly also in the international arena.

Figure 1 shows a diagram of activities that serve to organize well the external and internal links of the unit. Transparency and a clear distribution of competences as well as a simple circulation of information are undoubtedly conducive to the implementation of innovation policy.

A characteristic feature of the German approach to innovation is its comprehensiveness. Currently, many activities of both the German government and business-related institutions are directed towards digitization. This area is very financially supported but also included in long-term strategies - currently, Digitale Strategie 2025 is in force. The areas specifically described in this document are:

- development of the $1 \mathrm{~Gb}$ infrastructure,

- development of entrepreneurship (special emphasis is placed on start-up),

- development of SME sector companies,

- support the areas of Industrie 4.0 and personal data protection.

However, it should be stressed that this strategy is a continuation of previous multiannual documents. The implementation of the strategic assumptions is possible, among others, thanks to efficiently operating platforms. They bring together representatives of various environments and interest groups: economy, science, civil society, and politicians (Mazur \& Sobolewski, 2017). The Table 1 gives examples of entities operating in Ger- 
many whose activities are closely linked to the topic of digitization.

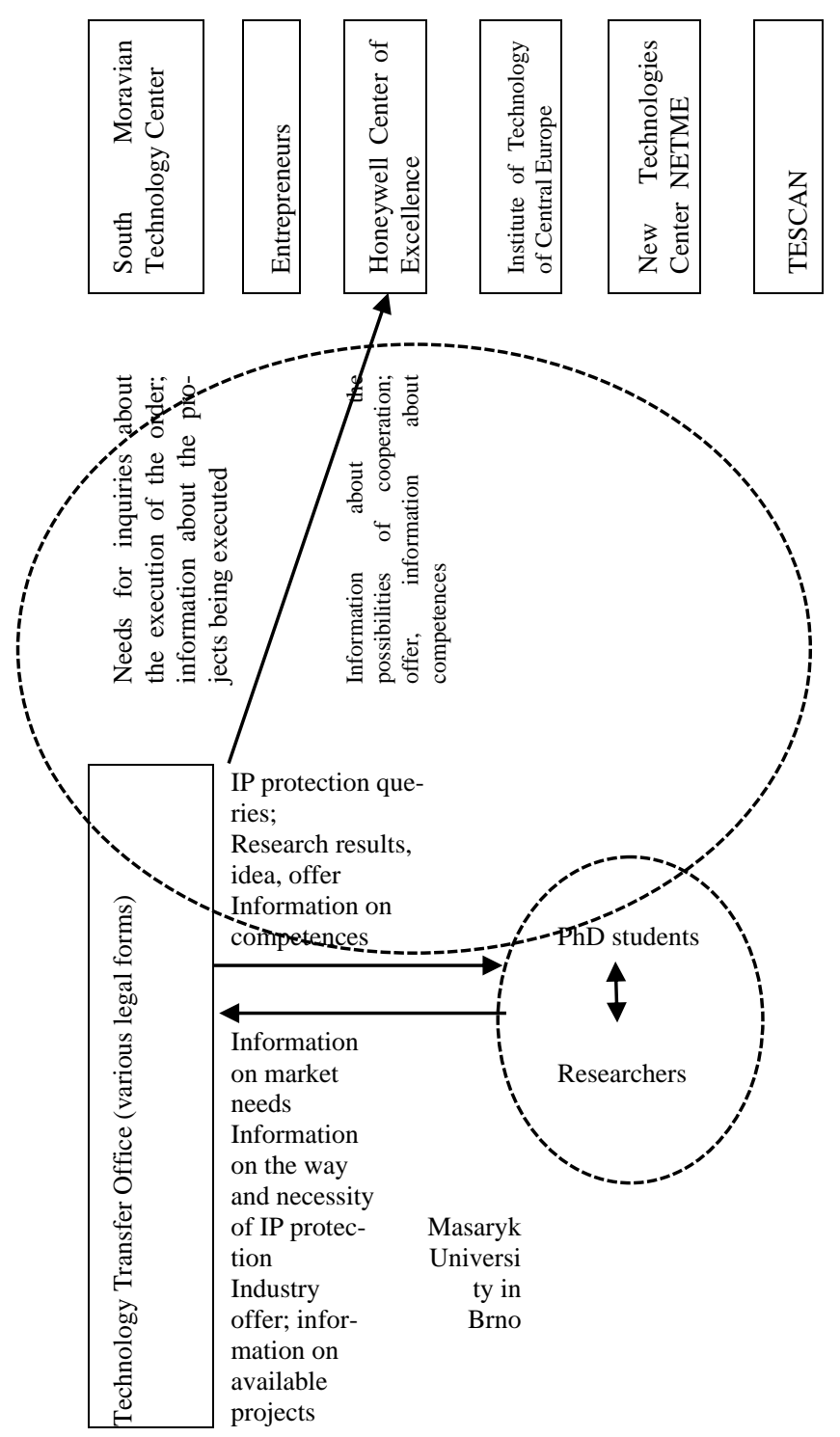

Figure 1. Relations between the Technology Transfer Office (TTO) of Masaryk University in Brno and the internal and external environment

(source: Trzmielak \& Grzegorczyk, 2016, p. 126)

In addition, the Nationalale IT-Gipfel (since 2017 Digital Gipfel) summit is held every year in Germany, which, together with the activities of the platforms and institutions presented above, guarantees the creation of appropriate solutions. In the document summarizing the conference in $2019-$ PlattFORM DIE ZUKUNFT, the most important challenges in the field of digitalization are presented:

- digital identity needs to be more secure and trustworthy, and data exchange procedures need to be strengthened;
- new business models and products can only be created if the necessary training data is available;

- European Commission and Member States must work together to protect and secure the data of citizens, businesses, industry, and administrations (PlattForm..., 2019, pp. 1-3).

Table 1. Actors supporting the digitisation process (source: own elaboration based on Mazur \& Sobolewski, 2017)

\begin{tabular}{|l|l|}
\hline \multicolumn{1}{|c|}{ Platforms } & \multicolumn{1}{|c|}{ Other entities } \\
\hline - Die Innovationsplattform & - Expertenkommission \\
Zukunftsstadt (The Innova- & Forschung und Innova- \\
tion Platform Future City) & tion (Expert Commis- \\
- Die Umsetzungsplatt- & sion for Research and \\
form Green Economy (The & Innovation) \\
Green Economy Imple- & - Hightech-Forum \\
mentation Platform) & - Innovationsdialog \\
- Die Nationale Plattform & zwischen Bundesre- \\
Bildung für nachhaltige & gierung, Wirtschaft \\
Entwicklung (The National & und Wissenschaft (In- \\
Platform of Education for & novation Dialogue \\
Sustainable Development) & between the Federal \\
- Die Forschungsinitiative & Government, Industry \\
Zukunft Bau (The Re- & and Science) \\
search Initiative Future & \\
Construction) & \\
- Das Forschungsforum & \\
Energiewende (the Re- & \\
search Forum on Energy & \\
System Transformation) & \\
- Die Energiewende- & \\
Plattform Forschung und & \\
Innovation (Research and & \\
Innovation Platform) & \\
- Die Forschungs- & \\
netzwerke Energie (The & \\
Energy Research Net- & \\
works) & \\
\hline
\end{tabular}

The digitization program includes many activities related to business activation, such as:

- The Ministry of Economy and Energy has the funds for companies to cover consultancy costs in the field of innovation,

- The Industry 4.0 platform is testing solutions for industry,

- The German Life Science Accelerator Programme helps the German startups in the process of the internationalization of their business operation (the target market is the US).

The financial support is also important - in the conditions of the German economy, this is 
clearly visible in the area of newcomer financing in 2016, 35\% of the start-ups in Germany used a very wide range of financing possibilities. The project Zentrales Innovationsprogramm Mittelstand (ZIM SOLO and KOOP) is worth mentioning here. Its main objective is to support the innovativeness of companies in the SME sector and to assist in internationalization processes. In 2015-2017, the support in this program amounted to 1178912 million euros. The Table 2 presents the amount of support broken down by sectors.

Table 2. The amount of support allocated to projects financed under the ZIM Programme 2015-2017 by sector. Amounts in millions of euros (source: Mazur \& Sobolewski, 2017, p. 11)

\begin{tabular}{|l|c|}
\hline \multicolumn{1}{|c|}{ Sector of activity } & $\begin{array}{c}\text { Support in millions } \\
\text { of euros }\end{array}$ \\
\hline Production technology & 299869 \\
\hline $\begin{array}{l}\text { Information and } \\
\text { communication technologies }\end{array}$ & 121521 \\
\hline $\begin{array}{l}\text { Electrical engineering, } \\
\text { metrology, sensors }\end{array}$ & 152850 \\
\hline Materials technology & 119326 \\
\hline $\begin{array}{l}\text { Medical research and health, } \\
\text { medical technology }\end{array}$ & 100300 \\
\hline Building Technologies & 64876 \\
\hline Other technologies & 54987 \\
\hline Biotechnology & 52281 \\
\hline Environmental technologies & 51569 \\
\hline Energy technologies & 49897 \\
\hline Optical technologies & 33807 \\
\hline Textile research & 31735 \\
\hline $\begin{array}{l}\text { Vehicle and communication } \\
\text { technologies }\end{array}$ & 24430 \\
\hline Microsystem technologies & 8242 \\
\hline Safety technologies & 7797 \\
\hline Nanotechnologies & 5429 \\
\hline Total & 178912 \\
\hline
\end{tabular}

However, the program also supports cluster initiatives by involving traditional companies with high innovative capacity as well as leaders in this area (Evaluation..., 2019, pp. 99-100). The initiative related to digitization was also created in Poland. On July 24th, 2019 the Minister of Entrepreneurship and Technology (MPiT) established the "Industry 4.0" Programme. In order to implement the program assumptions, two innovation hubs were selected. Their tasks will include, in particular:

- conducting information, demonstration, training and advisory activities,
- conduct actions promoting the idea of hubs,

- conducting an information campaign about the potential of industrial transformation and the effects on business models;

- conducting demonstration activities, thanks to which entrepreneurs will be able to get acquainted in a practical way with processes based on digital technologies, together with the possibility to use them in their company (process simulation, making prototypes);

- educational and training actions aimed at providing entrepreneurs and their (potential) employees with knowledge of digital technologies and the ability to use them;

- counseling, consisting of showing by the hub alternative solutions for introducing optimization or innovation in the methods of manufacturing products or providing services. Such cooperation may result in the preparation of a plan for the digital transformation of the business for the entrepreneur;

- implementation activities, e.g., in the form of assistance in integrating and launching new: machines, devices, and software;

- building a network for the exchange of competences and experience.

The proper implementation of the project will be supervised by the Steering Committee with the participation of representatives of MPiT and the Future Industry Platform Foundation. The hub includes, among others, the Krakow Technology Park, Wrocław University of Science and Technology, Poznan Science and Technology Park of Adam Mickiewicz University Foundation, VoiceLab.AI, and the The National Institute of Telecommunications - the State Research Institute.

The importance of this undertaking should be stressed - the emergence of such initiatives is particularly important for the Polish economy, which is not a leader in competitiveness rankings, and its innovativeness is also poorly evaluated (Czyżewska, 2016, p. 57). Such systemic support for science-business links is a clear signal that politics is turning into real programs that can contribute to increasing competitiveness.

Hubs started operating at the end of 2019 , and the program will run until 2021. 


\section{Science-business cooperation in the light of theory and research}

Modern economies are characterized by very high importance of knowledge and information. The proper collection and processing of information and the use of knowledge are one of the elements necessary to create innovative processes in an enterprise (Nazarko, 2013). In order for the elements of this system to function effectively, enterprises must look for business partners with whom they will create joint projects. One of such cooperation is science-business links. This collaboration can be carried out according to Figure 2.

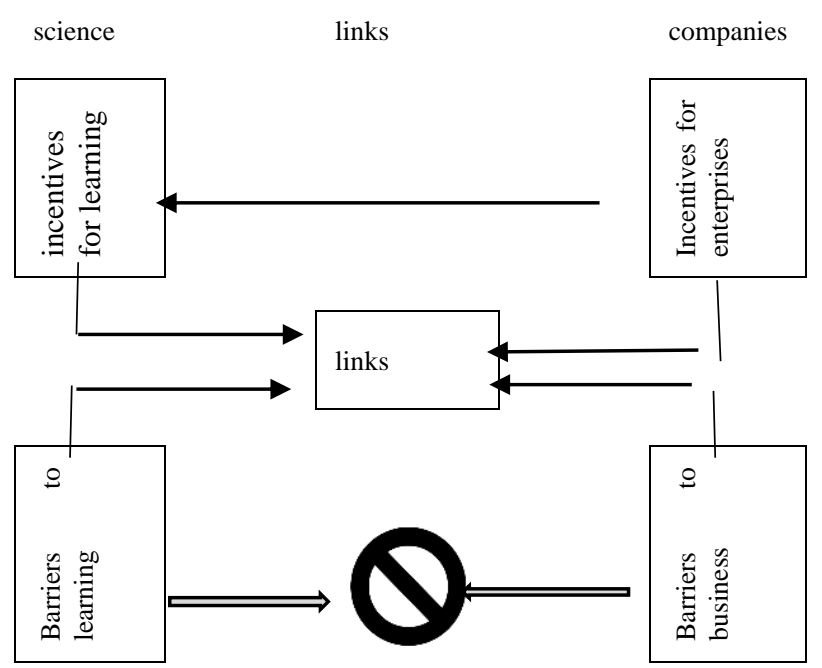

Figure 2. Science-business cooperation (source: Mackiewicz, 2007, p. 55)

Dynamic changes in management processes have made it necessary to move away from the approach that innovations, new solutions are created in universities or scientific entities and then absorbed by the business. The shape of modern economies makes it virtually impossible to speak of one direction of the flow of innovations - inventions are more and more often the domain of innovative enterprises, and solutions found there are implied by research institutes or units (Jasiński \& Ludwicki, 2007; Klaus-Rosińska, 2019).

Cooperation between science and business may take various forms, but most often following are mentioned: commissioned services, research grant with the use of results by business, joint venture, a business company with the university, an R\&D company, spin-off, recruitment of university graduates, staff exchange, conducting joint research, creation of joint patents and publications, licensing, opening of laboratories, research grants, but also maybe informal contacts such as meetings or conferences (Kulawczuk, 2010, p. 45; KunaMarszałek \& Lisowska, 2010).

\section{Barriers to the commercialization of research}

The process of commercialization of research is an element of, but also a result of cooperation between science and business; it encounters many limitations. They occur both on the side of enterprises and the sphere of science, but also concern other business-related areas. The specific nature of these limitations allows us to group them into the following sets, which are not homogeneous, the allocation of its elements is not stable, and their assignment to a particular set may be questionable, which is due to the multi-faceted nature of this issue. The characteristics of selected groups of constraints are presented below.

Structural limitations (barriers) - they are rooted in the Polish economy itself, which is not an innovative economy, characterized by uneven regional development. These limitations also result from the passivity and lack of involvement of business-related institutions in economic processes. A noticeable problem is also the research and development sector itself, whose entities rarely create and apply policies and strategies of cooperation with external entities. Therefore, it can be concluded that structural barriers are most strongly (as compared to others) related to the lack of tradition of science-business cooperation in the Polish economy. Among these barriers most often mentioned are:

- the lack of developed strategies and methods of cooperation, whose main objective would be to implement the cooperation,

- extensive contest rules (maybe a competence barrier) and inefficient allocation of EU funds,

- difficulties in obtaining credit (maybe a psychological barrier - heavy burden, liability).

System barriers are primarily related to the legal sphere. The biggest problem in this aspect seems to be solution relating to academic entrepreneurship (Santarek et al., 2008) - the creation of spin-off enterprises, transfer of intangible goods from science to business (both in the fiscal aspect and the issues of industrial property law and intellectual property protection (Byczko \& Trzmielak, 2013)). Therefore, the most frequently mentioned system barriers are:

- overregulation and legal acts,

- a mismatch between regulation and the challenges of an innovative economy, 
- unsatisfactory support for advisory units (e.g., technology transfer centers),

- underestimating the role of women in the scientific community and underestimating their competences as high-level employees in innovation units,

- negative selection (low wages in the science sector) (Łobejko \& Sosnowska, 2013; Matusiak \& Guliński, 2010; Wycisk \& Płaszczyca, 2019, p. 9).

However, according to the research carried out (Wycisk et al., 2018, p. 35), low wages in the academic sector are not the only problem to develop a career in such a way to favor the establishment of relationships with business.

In the opinion of researchers, the most effective and desirable are trips and internships abroad in the academic and non-academic sectors, and networking, training, and workshops on research topics. Among other things, young researchers list the following tools presented in Table 3.

Table 3. Additional tools to support career development particularly effectively (source: Wycisk et al., 2018)

\begin{tabular}{|l|}
\hline Very often \\
\hline - grant \\
- cooperation between universities and enterprises \\
- cooperation with a promoter (including mentoring \\
of experienced scientist) \\
\hline Often \\
\hline - to learn how to network \\
- implement implementation projects \\
- work in a research team, not individually \\
\hline Rarely \\
\hline - participate in an international grant \\
- combine theoretical experience with research prac- \\
tice \\
- to take up internships in companies \\
- take part in online training, especially on writing \\
grants \\
\hline Very rarely \\
\hline - develop knowledge and skills in the field of re- \\
search methodology \\
- make use of early childhood education \\
- involve training companies, business incubators \\
- conferences \\
- the popularization of science: blogs, activities in \\
associations \\
- working in editorial offices of scientific journals \\
\hline
\end{tabular}

Further barriers to awareness and culture (psychological) are mainly related to the low level of trust. This trust mainly concerns the suspicion of creating horizontal cooperation links (lack of faith in the good intentions of other participants in clusters or strategic alliances); entrepreneurs are also reluctant to use pro-innovative services, regardless of whether they are paid for or not. Symptoms of these barriers can also be found in the area of activity of regional authorities - most often, they use traditional methods of regional development, known for years. Unfortunately, the requirements of the modern economy require a broader perception of needs and opportunities - moving away from purely pro-public activities (supporting universities, research, and development units) and directing them also to the development of innovation in the public sector, i.e., creating science-business links using public-private links. It should be remembered that such links favor the processes of technology, innovation, or knowledge transfer (Janasz, 2004). Thus, among the barriers of awareness and culture, most often mentioned are:

- possible reduction of trust (entrepreneurs rarely use and underestimate the competence and reliability of regional innovation centers (often the services provided by such organizations are free of charge, or not much paid, which in the opinion of entrepreneurs means that they are also not worth much); moreover, innovation support centers are not perceived by regional authorities as an important link in the process of development and building the innovative capacity of regions).

- lack of understanding of the other party's work ethos, with high self-esteem of the relationship participants,

- no desire to commercialize,

- preferring the path of scientific development,

- innovative features of the leader and appetite for risk (Łobejko \& Sosnowska, 2013; Matusiak \& Guliński, 2010; Wycisk \& Płaszczyca, 2019, p. 9).

A separate group of barriers is those related to competence. Competence gaps or imperfections can be located on the side of regional authorities, academies, and businesses. The Table 4 shows the most important competence barriers that have been attributed to individual participants.

As shown by the results of the aforementioned research (Wycisk et al., 2018, p. 35), entrepreneurs also define factors that, in their opinion, impedes the development of science-business cooperation. The ideal model of cooperation requires the development of the following elements:

- presenting a specific offer by scientists to entrepreneurs, 
Table 4. Competence barriers (source: own analysis based on Łobejko \& Sosnowska, 2013; Matusiak \& Guliński, 2010; Wycisk \& Płaszczyca, 2019, p. 9)

\begin{tabular}{|c|}
\hline Regional authority \\
\hline $\begin{array}{l}\text { - lack of knowledge about growth industries and cre- } \\
\text { ative sectors } \\
\text { - the absence of a link between regional strategies } \\
\text { and smart specialization } \\
\text { - persistence of ossified connections }\end{array}$ \\
\hline Entrepreneurs \\
\hline $\begin{array}{l}\text { - lack of an intellectual property rights strategy (IP } \\
\text { strategy). An additional disadvantage in this area is } \\
\text { the level of patent fees, which is a very heavy finan- } \\
\text { cial burden, especially for small enterprises in the } \\
\text { initial phase of development }\end{array}$ \\
\hline The scientific area \\
\hline $\begin{array}{l}\text { - lack of education of personnel dedicated to } \\
\text { knowledge commercialization (knowledge of meth- } \\
\text { ods of invention market analysis, valuation of the } \\
\text { market value of an invention, building a marketing } \\
\text { strategy for it) } \\
\text { - the style of university management, based on ossi- } \\
\text { fied structures and solutions, does not favor the crea- } \\
\text { tion of new external links } \\
\text { - low awareness of employees about the essence of } \\
\text { inventiveness, the patenting process, commercializa- } \\
\text { tion mechanisms, requirements, and threats } \\
\text { - academic enterprises that are being established are } \\
\text { usually managed by people with a huge range of the- } \\
\text { oretical knowledge, but they do not know the realities } \\
\text { of the functioning of modern innovative companies } \\
\text { according to market requirements. This is due to, } \\
\text { among other things, the lack of effectively function- } \\
\text { ing apprenticeship or internship programs } \\
\text { - academic teachers have very narrow specializa- } \\
\text { tions, which makes them unable to convey } \\
\text { knowledge about the functioning of business entities } \\
\text { in an interdisciplinary manner }\end{array}$ \\
\hline Others \\
\hline $\begin{array}{l}\text { - the specificity of the Polish economy - mostly } \\
\text { these are micro-enterprises, which are underfunded, } \\
\text { mostly not employing professionals with narrow spe- } \\
\text { cializations. Therefore they are rather not interested } \\
\text { in making links with science and participating in the } \\
\text { process of knowledge commercialization } \\
\text { - lack of entities willing to finance "technical" inno- } \\
\text { vations. Existing entities, such as guarantee or loan } \\
\text { funds, focus their activities rather on securities lend- } \\
\text { ing } \\
\text { - the need to work outside the comfort zone of their } \\
\text { competences (e.g., a scientist developing a business } \\
\text { plan and being a team manager) } \\
\text { - effective teamwork of people with different compe- } \\
\text { tencies is difficult }\end{array}$ \\
\hline
\end{tabular}

- education by universities of personnel adapted to the contemporary economic reality and specificity of the market,

- supporting the business with broader scientific horizons and expertise,

- joint development of solutions to higher RTL levels,

- more frequent working meetings with representatives of science (permanent, direct contact),

- increasing the experience of scientists through internships in the economy,

- to enable the reconciliation of scientific and economic development,

- change the rules of financing the sciencebusiness cooperation.

As you can see, the last two postulates are in line with the expectations of scientists. Taking into account the requirements of the modern economy, entities making laws in the economic or scientific area should be reliable readers of reports on the commercialization of research, and their results should be taken into account when creating new legal solutions.

\section{Conclusions}

Although the level of innovativeness of the Polish economy is quite low, it is pleasing to see that there are more and more initiatives supporting the level of innovativeness in Poland. As it has been stressed many times, a competitive economy cannot be built without supporting and shaping science-business links. However, such links rather do not concern the participation of representatives of only these two groups - the greatest effect can be achieved by joining the administration and other business-related organizations. An example of care for the development of innovative entities, in connection with the scientific (expert) area, can be the Start in Poland Programme. This program covers the following groups: innovators and owners of young innovative companies (support in the implementation of projects), investors, the customer community (as income generators), institutions and mentors (they will teach, advise on how to build an innovative company and how to keep it on the market).

In order to talk about an innovative economy, more initiatives such as the Start in Poland Programme or Innovative Hubs are needed in Poland. However, these cannot be ad hoc actions, but wellthought-out and structured economic policy.

The requirement for competitiveness, not only within the Polish economy, is to use the ad- 
vantages of the knowledge-based economy - lifelong learning, supporting innovation, especially within modern technologies, development based on smart specializations, creating an organizational culture connected with the process of learning and knowledge management - intelligent and learning organizations. The use of these elements is necessary in order to create a solid and effective basis for creating links between science and business. This is not simple but possible. Given the varying degrees of involvement of the economies, it is important to learn and use good practices, but also to seek the best methods of adapting them to national conditions. Therefore, it is important to learn system solutions (e.g., German economy), use activities that have proven their worth in other countries (e.g. Czech Republic), establish cooperation with geographical areas for which science-business links are little known (e.g. Bulgaria). It is also important to strengthen the awareness of the benefits of parties joining such initiatives - here, it is important to create publications characterizing the achievements of other countries, but also EU documents describing good practices. Decisionmakers in the SME sector should realize that a necessary condition for the company's survival and development is to conduct innovative activities and research and development work on a permanent basis, and thus to set budgets focused on this area. Only basing the business model on such solutions may contribute to strengthening competitiveness.

Another extremely important issue is to make the innovativeness of enterprises a priority for the economic development of the country. The provisions included in the strategic documents will result in systematic and coordinated actions in this respect.

Moreover, according to the authors, the activities that can strengthen science-business links are the dissemination of the concept of open innovation, which will include a mechanism for comprehensive company improvement; development of a system of financial gratifications for researchers and building a system that guarantees the commercial use of research results. It is also worth considering, at the national level, the concepts of combining innovation development centers and other scientific entities in order to make optimal use of their potential and strengthen knowledge and technology transfer. At the level of the participants of such links, it is necessary to reduce bureaucracy in universities, which slows down the decisionmaking process, as well as taking care of mutual relations and taking responsibility for the entities shaping the tradition of cooperation between sci- ence and business as an act necessary for a competitive economy. The considerations presented above are an introduction to extensive research on the creation of a model of a triad of businessscientific-administrative cooperation, for which the authors' parent company is preparing.

\section{References}

Białasiewicz, M. (Ed.). (2009). Uwarunkowania $i$ sposoby wzrostu konkurencyjności przedsiębiorstw [Conditions and ways to increase the competitiveness of enterprises]. Uniwersytet Szczeciński.

Byczko, S., \& Trzmielak, D. M. (2013). Własność intelektualna na uczelni $i \quad w$ działalności gospodarczej. Analiza porównawcza i praktyczne aspekty funkcjonowania systemu patentowania $w$ Polsce $i$ wybranych krajach [Intellectual property at university and in business. Comparative analysis and practical aspects of functioning of the patent system in Poland and selected countries]. Centrum Transferu Technologii UŁ.

Czyżewska, D. (2016). Cele i narzędzia współpracy nauka-biznes w dokumentach strategicznych UE i Polski [Objectives and tools of science-business cooperation in EU and Polish strategic documents]. In Studia Ekonomiczne. Zeszyty Naukowe Uniwersytetu Ekonomicznego w Katowicach.

Evaluation, des Zentralen Innovationsprogramms Mittelstand (ZIM) [Evaluation of the Central Innovation Programme for SMEs (ZIM)]. (2019). Richtlinie 2015 Endbericht, Wien. Retrieved February 12, 2020 from

https://www.zim.de/ZIM/Redaktion/DE/Publikatio nen/Studien-Evaluationen/evaluation-zim-201907.pdf?_blob=publicationFile\&v $=11$

Gabryś, A. (2008). Najlepsze praktyki w zakresie wspótpracy ośrodków naukowych i biznesu przy wykorzystaniu środków z UE [Best practices for cooperation between research centers and business using EU funds]. Fundacja Aurea Mediocritas.

Głodek, P. (2019). Akademicki spin off. Wiedza zasoby $i$ ścieżki rozwoju [Academic spin off. Knowledge resources and pathways]. Uniwersytet Łódzki.

Janasz, W. (2004). Przedsiębiorczość w świetle uwarunkowań działanosci gospodarczej [Entrepreneurship in the light of the conditions of economic activity]. In. W. Janasz (Ed.), Innowacje w rozwoju przedsiębiorczości $w$ procesie transformacji [Innovation in the development of entrepreneurship in the transformation process] (pp. 17-59). Difin.

Jasiński, A. H., \& Ludwicki, D. (2007). Metodyka transformacji wyników badań naukowych do zastosowań praktycznych: raport [Methodology for transforming scientific results into practical applications: report]. Studia i Materiaty - Wydziat Zarządzania $U W$. 
Kaderabkova, A. (2007). Wspieranie relacji pomiędzy środowiskiem naukowym i przemysłem w regionach europejskich: dobre praktyki na przykładzie Republiki Czeskiej [Fostering relations between the scientific community and industry in European regions: good practices from the example of the Czech Republic]. In M. A. Weresa (Ed.), Transfer wiedzy $z$ nauki do biznesu doświadczenia regionu Mazowsze [Transfer of knowledge from science to business Mazovia region experience] (pp. 375-392). Szkoła Główna Handlowa. Oficyna Wydawnicza.

Klaus-Rosińska, A. (2019). Sukces projektów badawczych $i$ badawczo-rozwojowych $w$ sektorze nauki [Success of research and development projects in the scientific sector]. Politechnika Wrocławska.

Kulawczuk, P. (2010). Konstruowanie modeli biznesowych współpracy nauki i biznesu w realizacji działalności badawczo - rozwojowej [Building business models for cooperation between science and business in the implementation of research and development activities]. In. P. Kulawczuk (Ed.), Budowa wspótpracy nauki $z$ biznesem $w$ Województwie Lubelskim [Building cooperation between science and business in Lubelskie Voivodeship] (pp. 43-61). Instytut Badań nad Demokracją i Przedsiębiorstwem Prywatnym.

Kuna-Marszałek, A., \& Lisowska, R. (2010). Współpraca sfery nauki i przedsiębiorstw- przegląd badań [Cooperation between science and business - research review]. In J. Różański (Ed.), Wspótpraca nauki i biznesu jako czynnik wzmacniający innowacyjność regionu łódzkiego [Cooperation between science and business as a factor strengthening innovation in the Łódź region] (pp. 13-42). Wydawnictwo Biblioteka.

Łobejko, S., \& Sosnowska, A. (2013). Komercjalizacja wyników badań naukowych praktyczny poradnik dla naukowców [Commercialisation of research results practical guide for researchers]. Urząd Marszałkowski Województwa Mazowieckiego w Warszawie.

Mackiewicz, M. (2007). Instrumenty wspierania powiązań nauka- biznes w świetle teorii [Instruments to support science-business links in the light of theory]. In M. A. Weresa (Ed.), Transfer wiedzy $z$ nauki do biznesu doświadczenia regionu Mazowsze [Transfer of knowledge from science to business Mazovia region experience] (pp. 41-74). Szkoła Główna Handlowa, Oficyna Wydawnicza.

Matusiak, K. B., \& Guliński, J. (Eds.). (2010). System transferu technologii $i$ komercjalizacji wiedzy $w$ Polsce. Sity motoryczne $i$ bariery [Technology transfer and knowledge commercialization system in Poland. Motor forces and barriers]. PARP.

Mazu, J., \& Sobolewski, M. (2017). Systemowe wsparcie dla cyfryzacji gospodarki Przykład Niemiec [Systemic support for the digitisation of the econ- omy. Example of Germany]. Retrieved February 17, 2020 from

http://www.delab.uw.edu.pl/wp-content/uploads/ 2017/05/dobre_praktyki_niemcy.pdf

Moczała, A., Ejsmont, A., \& Klemens, B. (2016). Klastry kooperujace $i$ konkurujace organizacje sieciowe [Co-operating clusters and competing network organisations]. Texter.

Nazarko, J. (2013). Regionalny foresight gospodarczy. Scenariusze rozwoju innowacyjności mazowieckich przedsiębiorstw [Regional economic foresight. scenarios for development of innovativeness of mazovian enterprises]. Związek Pracodawców Warszawy i Mazowsza.

Patalas-Maliszewska, J. (2019). Modele referencyjne zarzadzania wiedza $w$ przedsiębiorstwie produkcyjnym [Reference models for knowledge management in a production company]. PWN.

"PlattFORM DIE ZUKUNFT" Dortmund Declaration zum Digital-Gipfel 2019 ["PlattFORM THE FUTURE" Dortmund Declaration for the 2019 Digital Summit]. (n.d.). Retrieved February 12, 2020 from

https://www.de.digital/DIGITAL/Redaktion/DE/Di gital-Gipfel/Download/2019/dortmund-

declaration-zum-digital-gipfel-

2019.pdf?_blob=publicationFile\&v=5)

Santarek, K., Bagiński, J., Buczacki, A., Sobczak, D., \& Szerenos, A. (2008). Transfer technologii z uczelni do biznesu. Tworzenie mechanizmów transferu technologii [Technology transfer from university to business. Creating technology transfer mechanisms]. PARP.

Stawicka, M., \& Noga, M. (Eds.). (2008). Globalizacja a konkurencyjność $w$ gospodarce światowej [Globalisation and competitiveness in the global economy]. CEDEWU.

Szopik-Depczyńska, K., Kędzierska-Szczepaniak, A., \& Kładź-Postolska, K. (2018). Innowacje $w$ gospodarce. Sfera $B+R$, finansowanie innowacji, klastry - wybrane aspekty [Innovation in the economy. The R\&D sphere, financing of innovations, clusters - selected aspects]. Wydawnictwo Naukowe Sophia.

Trzmielak, D. M., \& Grzegorczyk, M. (2016). Transfer wiedzy $i$ technologii $z$ organizacji naukowobadawczych do przedsiębiorstw [Knowledge and technology transfer from research organisations to enterprises]. WUŁ.

https://doi.org/10.18778/8088-526-4.01

Wycisk, A., \& Płaszczyca, M. (2019) Skuteczna wspótpraca nauka-biznes $w$ opinii przedsiębiorców. Raport [Effective cooperation between science and business in the opinion of entrepreneurs. Report]. Dział Badań i Analiz CZIiTT PW.

Wycisk, A., Kałamarz, M., Chojecki, J., Parzych, D., Modrzejewska, K., \& Wiśniewska, A. (2018). Potrzeby i oczekiwania młodych naukowców zwiazane $z$ rozwojem zawodowej kariery naukowej. 
Raport z badania spolecznego [The needs and expectations of young researchers for their career development. Social research report]. Krajowy Punkt
Kontaktowy Programów Badawczych Unii Europejskiej w Instytucie Podstawowych Problemów Techniki Polskiej Akademii Nauk. 